DE

\title{
Banking Competition and Efficiency: Empirical Analysis on the Bosnia and Herzegovina Using Panzar-Rosse Model
}

\author{
Deni Memić \\ University Sarajevo School of Science Technology, Faculty of Economics, Bosnia and \\ Herzegovina
}

\section{Abstract}

Background: Competition in the banking industry has been an important topic in the scientific literature as researchers tried to assess the level of competition in the banking sector. Objectives: This paper has an aim to investigate the market structure and a long term equilibrium of the banking market in Bosnia and Herzegovina nationwide as well as on its constitutional entities as well as to evaluate the monopoly power of banks during the years 2008-2012. Methods/Approach: The paper is examining the market structure using the most frequently applied measures of concentration k-bank concentration ratio (CRk) and Herfindahl-Hirschman Index (HHI) as well as evaluating the monopoly power of banks by employing Panzar-Rosse "H-statistic". Results: The empirical results using CRk and HHI show that Bosnia and Herzegovina banking market has a moderately concentrated market with a concentration decreasing trend. The Panzar-Rosse "H-statistic" suggests that banks in Bosnia and Herzegovina operate under monopoly or monopolistic competition depending on the market segment. Conclusions: Banks operating on the banking market in Bosnia and Herzegovina seem to be earning their total and interest revenues under monopoly or perfectly collusive oligopoly.

Keywords: Bosnia and Herzegovina; Herfindahl-Hirschman Index; Panzar-Rosse model; Banking; Market system; Monopolies; Competitive strategy

JEL classification: G21, D40, D50, L1 1

Paper type: Research article

Received: 26th July, 2014

Accepted: 15 th February, 2015

Citation: Memić, D. (2015). "Banking Competition and Efficiency: Empirical Analysis on the Bosnia and Herzegovina Banking Industry Using Panzar-Rosse Model", Business Systems Research, Vol. 6, No.1, pp. 72-92.

DOI: $10.1515 /$ bsrj-2015-0005

\section{Introduction}

Banks have an ultimate goal to create loans enhancing the financial flows in the economy generated from the collected deposit base. Having the role of the financial intermediation the financial system should by definition enhance efficiency and competitiveness on the financial market. 
The wealth and the profitability of banks' customers is highly affected by the competition on the banking sector through the tendency of lowering the products and service costs (Ritter, Silber, Udell, 2014).

Competition has been in the scientific and practical focus in the past decades, not only in the banking but also in other business industries around the world. Most of the previous research focuses on the competitive behaviour in one or several countries, using the respective baking industry data sets (Abdul Majid \& Sufian, 2007, Al-Muharrami, 2009a, Al-Muharrami 2009b, Anzoategui, Martinez, \& Rocha, 2012, Bikker \& Groeneveld, 1998, Coccorese, 2013, Hondroyiannis \& Papapetrou, 1999). Even though the existing literature does not unfold a unique approach towards the problem of competition on different banking markets, several approaches are common to most of the research. Bikker and Haaf (2002) note that the existing literature on measurement of competition can be divided into two major groups (a) Structure-Conduct-Performance (SCP) paradigm and the efficiency hypothesis (EH) paradigm on one side and (b) a number of formal approaches with roots in Industrial Organization theory.

The SCP methodology analyses if a highly concentrated market leads to collusive behaviour with larger banks which leads to their superior market performance. The efficiency hypothesis here tests whether it is the efficiency of larger banks that enables their superior market performance. The SCP paradigm relates the profitability to the market structure, using the number of banks/companies as exogenous variables in regressions of industrial profitability. The paradigm was criticized due to the theoretical possibility in which an industry has no entry and exit barriers which enables high level of competition in a highly concentrated market (Arrawatia \& Misra, 2012). One of the most commonly used measures for competition based on the structural approach is the Herfindahl-Hirschman index (Rhodes, 1993).

On the other side the non-structural models of competitive behavior have emerged such as Iwata model, the Bresnahan model, and the Panzar-Rosse (P-R) model (Panzar \& Rosse, 1982, 1987).

In recent years, significant number of research was focused on competition in the banking industry due to the fact that tendencies for liberalization, innovations and merger and consolidation of financial services sector have called for assessing the level of competition in the banking sector (Arrawatia \& Misra, 2012). Higher level of bank competition is expected to have a decreasing effect of bank product and service prices, which by theory lead to accelerated investments and economy growth. There are also potential negative effects of the increasing banking competition in the form of the increased risk appetite which may lead to decreasing profitability and efficiency (Mishkin, 2013).

The main purpose of this paper is to investigate the market structure of banking market in Bosnia and Herzegovina and to evaluate the monopoly power of banks operating in the Bosnian market during the period 2008-2012. Ever since the recent war, Bosnian banking market has undergone structural reforms which include privatization, modernization, financial integration, foreign capital inflow and the challenging effects of the global financial crisis.

This paper has a primary goal to measure the degree of competition in Bosnia and Herzegovina banking market as well as to investigate the possible impact of the market concentration on competition. The paper also focuses on the comparison of the Bosnian banking market with other banking markets, with regards to the levels of concentration and competition. 
Unlike in the European Union where the Economic and Monetary Union (EMU) has generally influenced a significant change of the financial framework, the Bosnian banking market is still to be considered as highly underdeveloped, despite of the fact that majority of the market share is held by the banks in the foreign (mainly EU banks) ownership.

Most of the reviewed literature focuses on the concentration and competition measurement using the Panzar-Rosse model (Panzar \& Rosse, 1982, 1987). This paper fills the gap in the literature by extending the geographical boundaries of the structural approach and Panzar-Rosse model application on assessing the competition and efficiency on the banking market in Bosnia and Herzegovina, since to our knowledge no similar research using data from Bosnia and Herzegovina has been conducted, with an exception to the study of performance analysis and benchmarking of commercial Banks from Bosnia and Herzegovina (Memić \& ŠkaljićMemić, 2013).

The organization of the paper is as follows. Section 2 presents the reviewed literature on the banking competition and efficiency. Section 3 presents the used methodology and data while Section 4 shows the results. Section 5 summarizes the paper with the concluding remark.

\section{Literature review}

The first use of the Panzar-Rosse H-statistic was conducted on the newspaper industry.

Several studies have measured the degree of competition and tested the market for equilibrium using structural and non-structural methods. One study used a panel data set covering the period from 1986 - 2004 using data from 67 different countries (Bikker, Shaffer, \& Spierdijk, 2009). The study has shown that Panzar-Rose price or revenue functions cannot be used to measure the degree of banking competition, as the authors concluded that the Panzar-Rosse H-statistic needs requires more information costs, market equilibrium and market demand elasticity.

De Rozas (2007) used data reported by Spanish depositary institutions covering the period from 1986 - 2005. The study uses $92 \%$ of aggregate assets of credit institutions sector, which is fairly representative and comprehensive. Author used the Panzar-Rosse methodology and has shown that the level of competition is higher than reported in the previous literature. Author has also reported that on the Spanish sample in case of large banks the market gets close to perfect competition, and no apparent relationship between competition and market is found.

Italian banking system has also been analysed using data from the period 19882000 with the final data set including 104 observations (Coccorese, 2002). The study uses non-linear simultaneous-equation model with an ultimate goal to identify the degree of competitiveness characterizing eight Italian largest banks. The study shows that the degree of competition on the Italian market is considerable and that there is no conflict between competition and concentration.

One paper evaluated the degree of competition among Italian banks between the period 1986-1996, also employing the Panzar-Rosse H-statistic (Coccorese, 2013). All of the used banks were classified into of the three groups on the basis of their respective size. The study uses total revenues as the dependent variable, as the models were created for each of the observed years. The results have shown that the model coefficients for the factor prices always positive and statistically significant. The main conclusion of the study is that the Italian banks have operated under the monopolistic competition in the period 1988-1996, and that the banks have been in the long-run equilibrium in only four of the observed years. 
Carbó, Humphrey, Maudos, \& Molyneux (2009) used banking market data from 14 European countries over the period 1995-2001, to assess the competition and pricing power in European banking. Among other indicators four indicators they used net interest margin, Lerner index, returns on assets, Panzar-Rosse $\mathrm{H}$-statistic, and $\mathrm{HHI}$ market concentration, and have shown that competition often gives conflicting predictions of competitive behavior across and within countries.

Another study assessed the degree of competitiveness in the banking industry of the EU in total as well as the degree of competitiveness in individual countries (Bikker \& Groeneveld, 1998). The data panel used in this study covers the period 1989- 1996 and have shown that mainly large banks play a greater role in the financial intermediation process. Their results suggest that national banking sectors in the EU are not identical.

Bikker \& Haaf (2000) applied the Panzar-Rosse model to banks from 23 European and non-European countries for the years 1988-1998. They have reported that banking markets in the industrial world are mainly operating under monopolistic competition. They also find that competition and bank size are proportional and that in some countries the competition has increased significantly over time.

Maudos \& Solís, (2009) have analysed the 43 commercial banks operating in Mexico over the period 1993-2005. The study uses net interest margin as the dependent variable and shows that it can be explained by average operating costs and by market power. The results show that net interest margin is mainly determined by average operating costs and the Lerner index (Maudos \& Solís, 2009).

Al-Muharrami (2009) analysed the market structure of the banking market of Saudi Arabia using data during the period 1993-2006. The Panzar-Rosse methodology results show that Saudi Arabia banking industry has a status of a monopolistic competition, and that the market is not highly concentrated as well as that it shows signs of concentration decline.

Greece banking market competition and concentration has also been assessed is several studies. Delis, Staikouras, \& Varlagas (2008) analyzed panel data of Greek banks over the period 1993-2004 and found that the static models used tend to underestimate the level of market power.

Number of other studies has used the Panzar-Rosse method to measure the degree of competition in the banking sector. Pruteanu-Podpiera, Weill, \& Schobert (2008) analyzed the Czech Banking Industry, Nathan \& Neave (1989) banks in Canada, Anzoategui, Martinez, \& Rocha (2010) applied similar methodology to the Middle East and Northern Africa Region, Mamatzakis, Staikouras, \& KoutsomanoliFillipaki (2005) analysed the degree of concentration and competition in the enlarged European Union banking environment over the period 1998-2002, Liu, Molyneux, \& Wilson (2013) measured competition and stability in 11 European countries over the period 2000-2008, Matthews, Murinde, \& Zhao (2007) reported an empirical assessment of competitive conditions among the major British banks, during a period of major structural change and found a monopolistic competition, Yildirim \& Philippatos (2007) used the data from eleven Latin American countries for the period 1993 to 2000 to find that banks appear to be earning their revenues under monopolistic competition, which was proven in many other developed and emerging financial systems.

To our knowledge, this is the first research conducted with the aim of measuring competition and efficiency of banks in Bosnia and Herzegovina using the PanzarRosse and $\mathrm{HHI}$ methodology. The significance of the research is that it offers an insight into the Bosnian banking market from the competition and efficiency 
perspective, which can be usefully in the desired country's economic integration into the European Union and its developed financial markets.

\section{Methodology}

\section{Structural approach: CRK and $\mathrm{HHI}$ indexes}

The structural approach to the measurement of competition from the SCP methodology has the goal to investigate whether a highly concentrated banking market can create an environment in which larger banks behave in a monopolistic direction. Such a behaviour usually causes collusive behaviour among banks which leads to an incensement of their profits. The SCP paradigm assumes that a higher bank concentration allows a higher degree of cooperation between them such that the banks might set higher prices and consequently gain substantial profits (Bain, 1956).

The EH paradigm suggests that market structure is determined by the efficiency whereas profits are generated by large firms since the concentration is highly dependent on efficiency. Both the SCP and EH approaches use the same measures of concentrations. These measures of concentrations are k-bank concentration ratio $\left(C R_{k}\right)$ and Herfindahl- Herschman Index $(\mathrm{HHI})$.

The Concentration ratio $\left(C R_{k}\right)$ shows the level of concentration within an observed industry, measured by the market share held by the substantially small number of firms (banks). CR takes the following form:

$$
C R_{k}=\sum_{i=1}^{n} M S_{i}=\sum_{i=1}^{n} \frac{i}{n}
$$

Whereas $M S_{i}$ represents the individual market shares of banks on the market. The market shares are usually calculated as the ratio of individual bank's assets to total industry assets. As there are no preset rules for an appropriate value of $k$, the total number of banks included in the analysis is usually an arbitrary decision (Tushaj, 2010), depending from the goal of the research and the size of the analyzed market. In the existing literature the value of $k$ is most commonly a combination of numbers 3 , $5,8,10$. The CR index may be considered as the concentration curve which ranges from zero to one, whereas the value of zero represents an infinite number of equally sized banks, while the value of one represents the situation in which the $k$ banks create the total industry.

The Herfindahl-Hirschman Index (HHI) is a statistical measure of a market concentration developed by the economists A.O. Hirschman and O.C. Herfindahl. $\mathrm{HHI}$ measure has reached a significant level of use ever since it was adopted by the Department of Justice of the Federal Reserve where it was used to measure the effects of mergers on competitiveness. This measure takes into consideration the number of firms (banks) by calculating their respective relative market shares (Rhoades, 1993). HHI is calculated as the sum of squares of market shares $\left(M S_{i}\right)$ of all individual banks $(i=1, \ldots n)$ taking participation on the analyzed market. This measure does not however take into consideration the geographic dimension of the bank concentration on one market and has been detected as relatively poor and unreliable measure of competition (Bikker et al., 2009; Shaffer, 1993; Shaffer and DiSalvo, 1994). HHI has the following form: 


$$
H H I=\sum_{i=1}^{n} M S_{i}^{2}
$$

The $\mathrm{HHI}$ index ranges between $1 / n$ and 1 and it can take the value of $1 / n$ when all banks in a market have an equal size. The other extreme value of $1 \mathrm{HHI}$ index reaches in the case of monopoly.

\section{Nonstrucutural approach: Panzar-Rosse model}

The weaknesses expressed by the structural or SCP and EH approaches are overrun by the new empirical industrial organization (NEIO). NEIO analyses the deviations between observed and marginal cost pricing, without using market structure indictors in order to assess the market concentration and competition (Al-Muharrami et al, 2006). These methods create models of industry equilibrium with the final outcome such that indicates the type of competitive conduct and estimates the reduced form revenue equations of the market participants. Such model is suggested by Panzar-Rosse (1987). John C. Panzar and James N. Rosse developed an empirical test which discriminates between different competitiveness market structures such as oligopoly, monopolistically competitive and perfectly competitive markets. Panzar-Rosse model (P-R model) creates a reduced-form equation $\left(R \wedge^{*}\right)$ that relates specific indicators of bank revenues to a set to vector of input prices as well as other variables. The model produces an indicator of competition called $\mathrm{H}$ statistic, which is calculated as the sum of elasticises of gross revenue with respect to given input process (Bikker et al., 2009).

The P-R model is based on the general equilibrium market model and assumes that banks will use different pricing strategies as a response to changes to their input prices, heavily depending on the competitive environment of the market (Rozas \& Luis, 2007).

The reduced form revenue equations $\left(R^{*}\right)$ of the market participants are derived from marginal revenue and cost functions and an equilibrium position which assumes zero profit. The zero profit condition is expressed as follows:

$$
R_{i}\left(y_{i}^{*}, Z_{i}^{R}\right)=C_{i}\left(y_{i}^{*}, W_{i}, Z_{i}^{C}\right)
$$

where $R_{i}(-)$ and $C_{i}(-)$ represent the revenue and cost functions for bank $i, y_{i}$ represents the output of the bank, $W_{i}$ represents the $K$-dimensional vector of factor input prices bank $i, W_{i}=\left(w_{1 i}, \ldots, w_{K i}\right), Z_{i}^{R}$ represents the vector of $J$ exogenous variables affecting the revenue function $Z_{i}^{R}=\left(Z_{1 i}^{R}, \ldots, Z_{j i}^{R}\right)$ and $Z_{i}^{C}$ represents the vector of $L$ exogenous variables affecting the cost function $Z_{i}^{R}=\left(Z_{1 i}^{C}, \ldots, Z_{j i}^{C}\right)$.

Observing at individual bank level marginal revenues must be equal to marginal costs, as follows:

$$
R_{i}^{\prime}\left(y_{i}^{*}, Z_{i}^{R}\right)=C_{i}^{\prime}\left(y_{i}^{*}, W_{i}, Z_{i}^{C}\right)
$$

Therefore the indicator given by the P-R model as elasticities of total revenues of an individual bank are calculated by the bank's input prices (). The sum of such elasticities is called H-statistic, which gives information about the competitive situation on the market, and is given as follows: 


$$
H=\sum_{k=1}^{K}\left(\frac{\partial R_{i}^{*}}{\partial w_{k i}} X \frac{w_{k i}}{R_{i}^{*}}\right)
$$

The interpretation of the P-R H-statistic depends on its value. Depending on the model, the H-statistic is used to measure (a) competitive environment and (b) market equilibrium.

$\mathrm{H}$-statistic with negative values indicates at monopoly or perfectly collusive oligopoly. Monopoly or perfectly collusive oligopoly assumes that a rise in input prices increases marginal costs and, by setting them equal to marginal revenues, reduces equilibrium output and the bank's revenues. Negative values of H-statistic can also be a product of the so-called operating in isolation whereas only weak substitutes to the product of the analyzed firm exist.

$\mathrm{H}$-statistic with values between 0 and 1 indicates monopolistic competition. In monopolistic competition there is product differentiation between the outputs of the different banks, the profit maximizing banks are confronted with a falling aggregate demand curve and behave like monopolists, which results in equalizing marginal costs and marginal revenues in the equilibrium state. By market exit and entry of imperfect substitutes, the demand curve always shifts in a way that the monopolist earns zero profits.

$\mathrm{H}$-statistic equal to 1 indicates perfect competition in market equilibrium, assuming that the banks' cost functions are linearly homogeneous to the factor prices, the production functions are homothetic, factor prices are exogenous to the individual bank, and the elasticity of the perceived demand of the individual firm is nondecreasing in the number of (symmetric) rivals as well as free market entry and exit (Panzar \& Rosse, 1987).

Panzar-Rosse $\mathrm{H}$-statistic can be used for a long-run equilibrium test with return on assets (ROA) as the dependent variable instead of the revenue or the price regression equation. If the value of $\mathrm{H}$-statistic is lower than $\mathrm{O}$ it indicates nonequilibrium, whereas $\mathrm{H}$-statistic equal to 1 indicates equilibrium.

Table 1

Competitive environment and equilibrium test

\begin{tabular}{|c|c|c|}
\hline Scenario & Value & Description \\
\hline \multicolumn{3}{|r|}{ Competitive environment } \\
\hline a & $\mathrm{H} \leq \mathrm{O}$ & Monopoly or perfectly collusive oligopoly \\
\hline b & $0<\mathrm{H}<1$ & Monopolistic competition \\
\hline c & $H=1$ & $\begin{array}{l}\text { Perfect competition, natural monopoly in a perfectly contestable } \\
\text { market, or sales maximizing firm subject to a break-even } \\
\text { constraint }\end{array}$ \\
\hline \multicolumn{3}{|r|}{ Equilibrium test } \\
\hline a & $\mathrm{H}<0$ & Disequilibrium \\
\hline b & $H=1$ & Equilibrium \\
\hline
\end{tabular}

Source: Panzar \& Rosse (1982, 1987), Molyneux et al. (1994).

In order to assess the H-statistic values this paper uses two revenue and one price equations, as well as a model with ROA as dependent variable for conducting the long-run equilibrium test.

The first revenue equation uses interest revenues as a dependent variable, and is given as follows: 


$$
\log I R=\alpha+\sum_{i=1}^{n} \beta_{i} \log \omega_{i}+\sum_{j} \gamma_{j} C F_{j}+\delta \log T A+\text { error }
$$

where,

$\begin{array}{ll}\text { Ln } & \text { - natural logarithm } \\ I R & - \text { Interest revenue } \\ \omega_{i} & - \text { factor prices } \\ C F_{j} & - \text { other bank specific variables } \\ T A & - \text { bank total assets } \\ \text { error } & \text { - total model error }\end{array}$

The second revenue equation uses interest revenues as a dependent variable, and is given as follows:

$$
\log T R=\alpha+\sum_{i=1}^{n} \beta_{i} \log \omega_{i}+\sum_{j} \gamma_{j} C F_{j}+\delta \log T A+\text { error }
$$

where,

$$
\operatorname{Tr} \quad \text { - total revenues }
$$

The $\mathrm{H}$-statistic for the two revenue equations will be the sum of the input price elasticities of total revenues or $H_{s}^{r}=\sum_{i=1}^{n} \beta_{i}$ (where $r$ stands for revenue and $s$ stands for scaled). These revenue models have been used in existing literature to assess the market structure and the level of (Philip Molyneux, Thornton, \& Michael LlyodWilliams, 1996; Nathan \& Neave, 1989; Shaffer, 2004).

The price equation uses total revenues divided by total assets (TR/TA) as a dependent variable, and is given as follows:

$$
\log \left(\frac{T r}{T a}\right)=\alpha+\sum_{i=1}^{n} \beta_{i} \log \omega_{i}+\sum_{j} \gamma_{j} C F_{j}+\delta \log T A+\text { error }
$$

where,

$$
\begin{array}{ll}
T r & \text { - total revenues divided by total assets }
\end{array}
$$

The $\mathrm{H}$-statistic for the price equation will be $H_{s}^{p}=\sum_{i=1}^{n} \beta_{i}$ (where $p$ stands for price and $s$ stands for scaled). The price model with total revenues divided by total assets has often been used in existing literature (Bikker et al., 2009; Phil Molyneux, LloydWilliams, \& Thornton, 1994; Schaeck, 2009; Yildirim \& Philippatos, 2007).

\section{Equilibrium test}

In order to test the long-run equilibrium Panzar-Rosse's H-statistic is used with a natural log of ROA as dependent variable (Molyneux et al., 1994; Majid \& Sufijan, 2006). As natural log cannot take negative values, and some of the observations from the Bosnian banking market recorded negative values of return on assets, a variable transformation in the form of $\log (1+R O A)$ was used. The long-run equilibtium test equation is given as follows: 


$$
\log (1+R O A)=\alpha+\sum_{i=1}^{n} \beta_{i} \log \omega_{i}+\sum_{j} \gamma_{j} C F_{j}+\delta \log T A+\text { error }
$$

where,

ROA - return on assets, measured as net result before tax divided by total assets

The long-run equilibrium test measures the sum of the elasticity of return on assets with respect to input prices. In the scenario of the $\mathrm{H}$-statistic (in some literature referred as E-statistic) taking the value of 0 or $H=\sum_{i=1}^{n} \beta_{i}=0$, the banking market is in long-run equilibrium. If the $\mathrm{H}$-statistic is not equal to 0 than the market is considered not to be in equilibrium (tested using F-test) as proposed in previous research (AlMuharrami, 2009a; Coccorese, 2013).

\section{Data and results}

Assessing the competition on the banking market in Bosnia and Herzegovina carries several problems. Due to the low level of awareness and resources, no research has been conducted on this topic using the data from the Bosnian banking market. Bosnian banking market is highly decentralized due to the constitutional provisions and consists of two separate banking markets / entities, each having their own regulations, regulatory authorities and none of them being the Central Bank. Lack of a centralized research database consisting of necessary financial data from the banking market is one of the main issues in conducting such a research.

All publicly available financial statements of banks operating in both entities in the panel period 2008-2012 are used in the empirical part of this research. As some of the banks' financial statements were not publicly available, they are not included in the sample. The data for 2007 are not included due to a relatively high share of missing financial statements. Table 2 gives an overview of the number of observations in the observed period.

Table 2

Number of observations in the observed period

\begin{tabular}{|c|c|c|c|c|c|c|}
\hline Year & $\mathbf{2 0 0 8}$ & $\mathbf{2 0 0 9}$ & $\mathbf{2 0 1 0}$ & $\mathbf{2 0 1 1}$ & $\mathbf{2 0 1 2}$ & Total \\
\hline Included \# of banks & 20 & 23 & 23 & 24 & 24 & 130 \\
\hline Total \# of banks & 30 & 30 & 29 & 29 & 28 & 178 \\
\hline \% included & $69,0 \%$ & $79,3 \%$ & $79,3 \%$ & $82,8 \%$ & $82,8 \%$ & $73,0 \%$ \\
\hline
\end{tabular}

Source: Author's calculations

The bank-years not included in the analysis are small banks, banks which faced bankruptcy procedures in the observed periods and one banks operating under principles of Islamic banking. The study also excludes development banks due to their different technology, structure and goal to the commercial banks (AlMuharrami, 2008). The included data relevance is insured as in all observed years the included share of total assets does not drop below $85 \%$ of total bank industry assets. The final dataset includes 140 observations. The data is obtained from both constitutional entities Federation of Bosnia and Herzegovina and Republika Srpska.

The Table 3 gives an overview of the calculated $C R_{3}, C R_{5}, C R_{8}$ and $\mathrm{HHI}$ indexes for loans, deposits and assets.

The $C R_{k}$ indicators calculated for loans, deposits and total assets show a decreasing concentration trend between 2008 and 2012. The concentration of loans 
for top three banks has decreased from 47,3\% in 2008 to $34,4 \%$ in 2012 . The similar trend was detected for top 5 and top 8 banks. The $\mathrm{HHI}$ index for loans ranged from 0,095 in 2008 and was decreased to 0,059 in 2012. The concentration indicators for deposits show a slight increase in all $C R_{3}, C R_{5}, C R_{8}$ groups in 2009 compared to 2008 indicating an increasing customer confidence in largest banks. The indicators were relatively unchanged in 2010, but were decreasing ever since. The $\mathrm{HHI}$ index for deposits has also increased from 0,101 in 2008 to 0,109 and 0,110 in 2009 and 2010 respectively. Following the $C R_{k}$ trends it has decreased in 2011 and 2012, indicating a decreasing concentration of deposits among large banks. As assets are mainly consisted of loans on the banking market in Bosnia and Herzegovina, $C R_{k}$ and $\mathrm{HHI}$ indicators for total assets are following the indexes for loans in the observed period. The asset concentration for the largest 3 banks has decreased from 47,5\% in 2008 to $39,6 \%$ in 2012 , for largest 5 banks from $62,6 \%$ to $51,8 \%$ and from $75,3 \%$ to $64,8 \%$ for largest 8 banks. The HHI indicator for assets has ranged from 0,099 in 2008 to 0,076 in 2012 and indicated a very low concentration. Generally the Bosnian market can be considered as one with very low concentration measured by Herfindahl-Hirschman Index applied to loans, deposits and total assets.

Table 3

Results of concentration ratios and Herfindahl-Hirschman Index

\begin{tabular}{|c|c|c|c|c|c|}
\hline Year & 2008 & 2009 & 2010 & 2011 & 2012 \\
\hline \multicolumn{6}{|c|}{ Loans } \\
\hline $\mathrm{CR}_{3}$ & $47,3 \%$ & $42,9 \%$ & $39,5 \%$ & $36,8 \%$ & $34,4 \%$ \\
\hline $\mathrm{CR}_{5}$ & $61,8 \%$ & $58,3 \%$ & $54,2 \%$ & $50,1 \%$ & $46,3 \%$ \\
\hline $\mathrm{CR}_{8}$ & $73,6 \%$ & $70,4 \%$ & $65,6 \%$ & $61,3 \%$ & $58,1 \%$ \\
\hline HHI & 0,095 & 0,083 & 0,073 & 0,066 & 0,059 \\
\hline \multicolumn{6}{|c|}{ Deposits } \\
\hline $\mathrm{CR}_{3}$ & $47,0 \%$ & $49,2 \%$ & $49,4 \%$ & $47,9 \%$ & $46,6 \%$ \\
\hline $\mathrm{CR}_{5}$ & $61,7 \%$ & $62,3 \%$ & $61,5 \%$ & $60,3 \%$ & $58,3 \%$ \\
\hline $\mathrm{CR}_{8}$ & $73,5 \%$ & $73,8 \%$ & $73,8 \%$ & $72,5 \%$ & $70,4 \%$ \\
\hline HHI & 0,101 & 0,109 & 0,110 & 0,107 & 0,102 \\
\hline \multicolumn{6}{|c|}{ Assets } \\
\hline $\mathrm{CR}_{3}$ & $47,5 \%$ & $47,0 \%$ & $43,3 \%$ & $41,1 \%$ & $39,6 \%$ \\
\hline $\mathrm{CR}_{5}$ & $62,6 \%$ & $60,7 \%$ & $56,5 \%$ & $54,3 \%$ & $51,8 \%$ \\
\hline $\mathrm{CR}_{8}$ & $75,3 \%$ & $74,0 \%$ & $69,7 \%$ & $65,3 \%$ & $64,8 \%$ \\
\hline HHI & 0,099 & 0,097 & 0,086 & 0,083 & 0,076 \\
\hline
\end{tabular}

Source: Author's calculations

The paper includes two revenue and one price equations, as well as a model with ROA as dependent variable for conducting the long-run equilibrium test. The first loglog revenue equation, with interest revenue as the dependent variable:

$$
\begin{aligned}
\log I R=C+ & \beta_{1} \log P F_{i}+\beta_{2} \log P L_{i}+\beta_{3} \log P K_{i}+\delta \log T A+\gamma_{1} \log C A P A S S_{i} \\
& +\gamma_{2} \log L O A N A S S_{i}+\gamma_{3} \log B R_{i}+\gamma_{4} \log L T D_{i}+\gamma_{5} D 5_{i} \\
& +\gamma_{6} D E_{i}+\text { error }
\end{aligned}
$$

where

$$
\begin{array}{ll}
L n & - \text { natural logarithm } \\
I R & - \text { interest revenue } \\
P F_{i} & - \text { ratio of interest expenses and total deposits }
\end{array}
$$




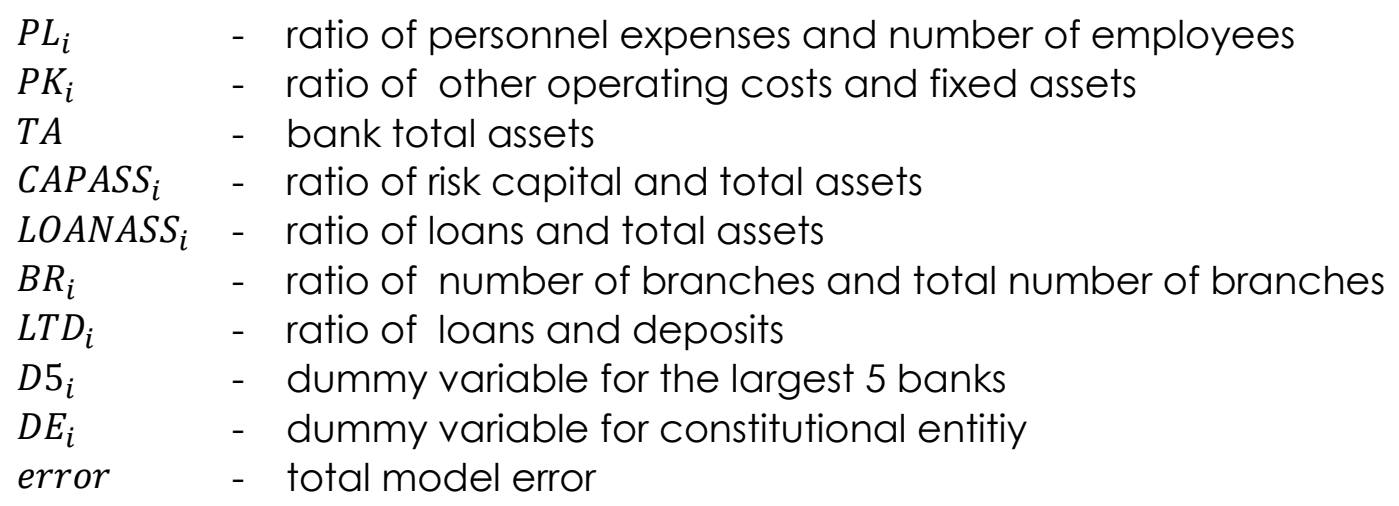

The second log-log revenue equation, uses total revenue as the dependent variable and is given as follows:

$$
\begin{aligned}
\log T R=C+ & \beta_{1} \log P F_{i}+\beta_{2} \log P L_{i}+\beta_{3} \log P K_{i}+\delta \log T A+\gamma_{1} \log C A P A S S_{i} \\
& +\gamma_{2} \log L O A N A S S_{i}+\gamma_{3} \log B R_{i}+\gamma_{4} \log L T D_{i}+\gamma_{5} D 5_{i} \\
& +\gamma_{6} D E_{i}+\text { error }
\end{aligned}
$$

The log-log price equation uses ratio of total revenues to total assets as the dependent variable and is given as follows:

$$
\begin{aligned}
\log \left(\frac{T R}{T A}\right) & =C+\beta_{1} \log P F_{i}+\beta_{2} \log P L_{i}+\beta_{3} \log P K_{i}+\delta \log T A \\
& +\gamma_{1} \log C A P A S S_{i}+\gamma_{2} \log L O A N A S S_{i}+\gamma_{3} \log B R_{i} \\
& +\gamma_{4} \log L T D_{i}+\gamma_{5} D 5_{i}+\gamma_{6} D E_{i}+\text { error }
\end{aligned}
$$

For the revenue and price equations $H-$ statistic $=\beta_{1}+\beta_{2}+\beta_{3}$.

In order to assess the long-run equilibrium Panzar-Rosse's $\mathrm{H}$-statistic the following equation is used:

$$
\begin{aligned}
\log (1+R O A)= & C+\beta_{1} \log P F_{i}+\beta_{2} \log P L_{i}+\beta_{3} \log P K_{i}+\delta \log A A \\
& +\gamma_{1} \log C A P A S S_{i}+\gamma_{2} \log L O A N A S S_{i}+\gamma_{3} \log B R_{i} \\
& +\gamma_{4} \log L T D_{i}+\gamma_{5} D 5_{i}+\gamma_{6} D E_{i}+\text { error }
\end{aligned}
$$

where the H-statistic is tested for equilibrium as $H-$ statistic $=\beta_{1}+\beta_{2}+\beta_{3}=0$.

All of the models are created for the whole country, as well as for each of the Bosnian entities. For the whole country P-R model with natural logarithm of interest revenue (IR) used as dependent variable, cost of funds $(P F)$ and cost of labor $(P L)$ have a statically significant effect on the interest income, with relatively high coefficients. Cost of funds $(P F)$ variable is positively related to interest income which can be justified by the fact that more deposit funds collected by the bank by theory leads to more loans and consecutively more interest income, ceteris paribus (significant at $1 \%)$. Cost of labor $(P L)$ variable is negatively related to interest income (significant at 5\%). The size of bank's assets $(A S S)$ as well as share of loans in total assets (LOANASS) is expectedly positively related to interest income and is significant at $1 \%$. Ratio of number of branches to total number of branches also exhibits 
expectedly a positive relationship to interest income, as bank has more branches, it should have more loan exposed customers (significant at 10\%). Loan to deposit ratio (LTD) seems to have a negative relationship with interest income. Indicator of largest five banks in Bosnia and Herzegovina as well as entity in which banks operate, does not seem to have statistically significant effect on the level of interest income. The Wald test does not reject the hypothesis of monopolistic market structure where $\mathrm{H}$ statistic $=0$ at the $5 \%$ significance level. It however rejects the hypothesis of perfectly competitive market structure where $\mathrm{H}$-statistic $=1$ at the $5 \%$ significance level. The estimation of $\mathrm{H}=0,084$ suggests that bank interest revenues in the sample period appear to be earned in conditions of monopolistic market structure on the banking market in Bosnia and Herzegovina.

P-R model created for Federation of Bosnia and Herzegovina with natural logarithm of interest revenue used as dependent variable, cost of funds $(P F)$ and cost of capital o $(P K)$ have a statically significant effect on the interest income. Both variables $(P F$ and $P K)$ variables are positively related to interest income. Cost of funds is significant at $1 \%$, while cost of capital is significant at $5 \%$. Cost of funds has significantly higher effect on the interest income than cost of capital. Unlike for the model created for on the whole country level, cost of labor has an insignificant effect on interest income. The size of bank's assets (ASS) as well as share of loans in total assets (LOANASS) is expectedly positively related to interest income and is significant at $1 \%$. Ratio of number of branches to total number of branches also exhibits expectedly a positive relationship to interest income, similar to the one detected on the country level. The Wald test does not reject the hypothesis of monopolistic market structure in Federation of Bosnia and Herzegovina where $\mathrm{H}$ statistic $=0$ at the $5 \%$ significance level. It however rejects the hypothesis of perfectly competitive market structure where $\mathrm{H}$-statistic $=1$ at the $5 \%$ significance level. The estimation of $\mathrm{H}=0,105$ suggests that bank interest revenues in the sample period appear to be earned in conditions of monopolistic market structure on the banking market in Federation of Bosnia and Herzegovina.

P-R model created for Republika Srpska with natural logarithm of interest revenue used as dependent variable, out of the three used factor prices, only cost of funds $(P F)$ have a statically significant effect on the interest income (significant at 1\%), with very high regression coefficient. The size of bank's assets (ASS) as well as share of loans in total assets (LOANASS) is expectedly positively related to interest income and is significant at $1 \%$. These rations are exhibiting similar effects on the dependent variable in all three models. Loan to deposit ratio (LTD) seems to have a negative relationship with interest income in Republika Srpska, similar to the country-level model. The Wald test rejects the hypothesis of monopolistic market structure in Federation of Bosnia and Herzegovina where H-statistic $=0$ at, as well as hypothesis of perfectly competitive market structure where $\mathrm{H}$-statistic $=1$ at the $5 \%$ significance level. The estimation of $\mathrm{H}=0,783$ indicates the conclusion that bank interest revenues in the sample period in Republika Srpska appear to be earned in conditions of monopolistic competition market structure.

The second revenue model is created on the basis of total revenues $(T R)$ as dependent variable. On the whole country level the following variables are statistically significant: $P F, P L, A S S, L O A N A S S, B R, L T D$, and DummyE. We remark that $P F, A S S, L O A N A S S, B R$ are in positive, while $P L, L T D$ and DummyE are in negative relation to total revenues. The cost of funds with a positive coefficient shows that the increased costs of funds leading to the higher revenue, while cost of labour with a negative sign implicates that the increased cost of labour leading to the lower total revenues. The Wald test rejects the hypothesis of monopolistic market structure in 
Federation of Bosnia and Herzegovina where $\mathrm{H}$-statistic $=0$ at $5 \%$ significance level, as well as hypothesis of perfectly competitive market structure where $\mathrm{H}$-statistic $=1$ at the $5 \%$ significance level. The estimation of $\mathrm{H}=-0,268$ indicates the conclusion that bank total revenues in the sample period in Bosnia and Herzegovina appear to be earned in conditions of monopoly or perfectly collusive oligopoly market structure.

For the model using total revenues as dependent variable using data from Federation of Bosnia and Herzegovina, the following variables are statistically significant: $P F, P L, A S S, B R$ and $L T D$. We remark that $P F, A S S, B R$ are in positive, while $P L, L T D$ are in negative relation to total revenues. The cost of funds with a positive coefficient shows that the increased costs of funds leading to the higher revenue, while cost of labour with a negative sign implicates that the increased cost of labour leading to the lower total revenues. The directions of the relationships between the dependent and independent variabels are the same as in the whole country model. The Wald test does not reject the hypothesis of monopolistic market structure in Federation of Bosnia and Herzegovina where $\mathrm{H}$-statistic $=0$ at $5 \%$ significance level. It however rejects the hypothesis of perfectly competitive market structure where $\mathrm{H}$ statistic $=1$ at the $5 \%$ significance level. The estimation of $\mathrm{H}=0,033$ indicates the conclusion that bank total revenues in the sample period in Federation of Bosnia and Herzegovina appear to be earned in conditions of monopoly or perfectly collusive oligopoly market structure.

For the model using total revenues as dependent variable using data from Republika Srpska, the following variables are statistically significant: $P F, A S S, B R$ and LTD. We remark that $P F, A S S, B R$ are in positive, while $P L, L T D$ are in negative relation to total revenues. The cost of funds with a positive coefficient shows that the increased costs of funds leading to the higher revenue, while cost of labour with a negative sign implicates that the increased cost of labour leading to the lower total revenues. The directions of the relationships between the dependent and independent variabels are the same as in the whole country model. The Wald test does not reject the hypothesis of monopolistic market structure in Federation of Bosnia and Herzegovina where $\mathrm{H}$-statistic $=0$ at $5 \%$ significance level. It however rejects the hypothesis of perfectly competitive market structure where $\mathrm{H}$-statistic $=1$ at the $5 \%$ significance level. The estimation of $\mathrm{H}=-0,058$ indicates the conclusion that bank total revenues in the sample period in Federation of Bosnia and Herzegovina appear to be earned in conditions of monopoly or perfectly collusive oligopoly market structure.

The P-R price model is created on the basis of ratio of total revenues to total assets (TR/TA) as dependent variable. On the whole country level the following variables are statistically significant: $P F, P L, A S S, C A P A S S, L O A N A S S, B R, L T D$, and DummyE. The model shows that PF, CAPASS, LOANASS, BR are in positive, while PL, ASS, LTD and DummyE are in negative relation to total revenues to total asset ratio. The Wald test rejects the hypothesis of monopolistic market structure in of Bosnia and Herzegovina where $\mathrm{H}$-statistic $=0$ at $5 \%$ significance level, as well as hypothesis of perfectly competitive market structure where $\mathrm{H}$-statistic $=1$ at the $5 \%$ significance level. The estimation of $\mathrm{H}=-0,268$ indicates the conclusion that bank total revenues in the sample period in Bosnia and Herzegovina appear to be earned in conditions of monopoly or perfectly collusive oligopoly market structure.

The model created with data from Federation of Bosnia and Herzegovina the following variables are statistically significant: $P F, P L, A S S, B R, L T D$. The model shows that PF, CAPASS, LOANASS, BR are in positive, while PL, ASS, LTD and DummyE are in negative relation to total revenues to total asset ratio. The Wald test did not reject the hypothesis of monopolistic market structure in of Bosnia and Herzegovina where 
$\mathrm{H}$-statistic $=0$ at $5 \%$ significance level. The Wald test rejected the hypothesis of perfectly competitive market structure where $\mathrm{H}$-statistic $=1$ at the $5 \%$ significance level. The estimation of $\mathrm{H}=0,033$ indicates that bank total revenues in the sample period in Federation of Bosnia and Herzegovina appear to be earned in conditions of monopoly or perfectly collusive oligopoly market structure.

The model created with data from Republika Srpska the following variables are statistically significant:PF, ASS, LOANASS, LTD. The model indicates thatPF, ASS, LOANASS are in positive, while $L T D$ is in negative relation to total revenues to total asset ratio. The Wald test did not reject the hypothesis of monopolistic market structure in of Bosnia and Herzegovina where $\mathrm{H}$-statistic $=0$ at $5 \%$ significance level. The Wald test rejected the hypothesis of perfectly competitive market structure where $\mathrm{H}$-statistic $=1$ at the $5 \%$ significance level. The estimation of $\mathrm{H}=-0,058$ indicates that bank total revenues in the sample period in Federation of Bosnia and Herzegovina appear to be earned in conditions of monopoly or perfectly collusive oligopoly market structure.

We also tested the banking market of Bosnia and Herzegovina as well as its entities for long-run equilibrium using an adequate transformation of ratio of pre-tax net profit to total asset $(1+\mathrm{ROA})$ as the dependent variable. The Wald test for models for whole country as well as for the Republika Srpska model do rejected the null hypothesis $H$-statistic $=0$, which indicated that in the observed period the two banking markets are not in a long run equilibrium, while the model for Federation of Bosnia and Herzegovina, shows that its banking market is in the long-run equilibrium, as the Wald test does not reject the hypothesis that $\mathrm{H}$-statistic $=0$.

\section{Conclusions}

This paper investigated the market structure of the banking market in Bosnia and Herzegovina and its constitutional entities using k-bank concentration ratio $\left(\llbracket C R \rrbracket \_k\right)$ and Herfindahl-Hirschman Index (HHI) and the monopoly of banks using the Panzar-Rosse H-statistic during the period of 2008 - 1012. The results show that the both concentration ratios calculated for loans, deposits and total assets are exhibiting fairly high level but have a decreasing trend between 2008 and 2012. The Panzar-Rosse $\mathrm{H}$-statistic suggests that banking market of Bosnia and Herzegovina observed as a whole and banking markets of constitutional entities that act as separate banking markets, tend to exhibit similar market structure results in most of the created models. Banks operating on the banking market in Bosnia and Herzegovina seem to be earning their total and interest revenues under monopoly or perfectly collusive oligopoly, with an exception for the Republika Srpska market in the model using interest revenues as dependent variable, with the H-statistic of 0,783 indicates monopolistic competition.

The estimates of the Panzar-Rosse H-statistics of a static model suggest that the Bosnia and Herzegovina Republika Srpska banking market were characterized by disequilibrium and equilibrium for Federation of Bosnia and Herzegovina over the period between 2008 and 2012. In other words the study has shown that there was some correlation between return on assets and the prices of used factor inputs. As to our knowledge no similar studies have been conducted so far on either the Bosnia and Herzegovina or to its neighbouring countries, no comparative conclusions are viable.

This research and its results are limited to one country and bank financial data published on their own or regulatory authorities' and financial markets' web sites. We propose further research in this area, using data from more than one developing country, and their comparison to results obtained for developed countries. Such 
insight may help understand if any competition or efficiency differences exist between developed and developing banking markets.

\section{References}

1. Abdul Majid, M. Z., Sufian, F. (2007), "Market Structure and Competition in Emerging Market: Evidence from Malaysian Islamic Banking Industry", MPRA Paper, available at: http://mpra.ub.uni-muenchen.de/12126/1/ / (June 12, 2014).

2. Al-Muharrami, S. (2009a), "Analysis of competitiveness in Qatar banking industry", International Journal of Business Innovation and Research, Vol. 3 No. 2, pp. 168181.

3. Al-Muharrami, S. (2009b), "The competition and market structure in the Saudi Arabia banking", Journal of Economic Studies, Vol. 36 No. 5, pp. 446-460

4. Al-Muharrami, S., Matthews, K., Khabari, Y. (2006), "Market structure and competitive conditions in the Arab GCC banking system", Vol. 30 No. 12, pp. 3487-3501.

5. Anzoategui, D., Martinez, P. M. S., Rocha, R. R. (2010), "Bank Competition in the Middle East and Northern Africa Region", Review of Middle East Economics and Finance, Vol. 6 No. 2, pp. 26-48.

6. Anzoategui, D., Pería, M. S. M., Melecky, M. (2012), "Bank competition in Russia: An examination at different levels of aggregation", Emerging Markets Review, Vol. 13 No. 1, pp. 42-57.

7. Bain, J. S. (1956), "Barriers to new competition: their character and consequences in manufacturing industries", Cambridge, MA: Harvard University Press.

8. Bikker, J. A., Groeneveld, J. M. (1998), "Competition and Concentration in the EU Banking Industry", Research Series Supervision, Netherlands Central Bank, Directorate Supervision.

9. Bikker, J. A., Haaf, K. (2002), "Competition, concentration and their relationship: An empirical analysis of the banking industry", Journal of Banking \& Finance, Vol. 26. No. 11, pp. 2191-2214.

10. Bikker, J. A., Shaffer, S., Spierdijk, L. (2009), "Assessing competition with the PanzarRosse model: the role of scale, costs, and equilibrium", Review of Economic and Statistics, Vol. 94, No. 4, pp. 1025-1044.

11. Brämer, P., Gischer, H., Richter, T., Weiß, M. (2013), "Competition in banks' lending business and its interference with ECB monetary policy", Journal of International Financial Markets, Institutions and Money, Vol. 25, pp. 144-162.

12. Carbó, S., Humphrey, D., Maudos, J., Molyneux, P. (2009), "Cross-country comparisons of competition and pricing power in European banking", Vol. 28. No. 1, pp. 115-134.

13. Chen, S.-H., Liao, C.-C. (2011), "Are foreign banks more profitable than domestic banks? Home- and host-country effects of banking market structure, governance, and supervision", Journal of Banking \& Finance, Vol. 35. No. 4, pp. 819-839.

14. Coccorese, P. (2002), "Competition Among Dominant Firms in Concentrated Markets: Evidence from the Italian Banking Industry", Working Paper No. 89. Centre for Studies in Economics and Finance (CSEF), University of Naples, Italy.

15. Coccorese, P. (2004), "Banking competition and macroeconomic conditions: a disaggregate analysis", Journal of International Financial Markets, Institutions and Money, Vol. 14. No. 3, pp. 203-219.

16. Coccorese, P. (2005), "Competition in markets with dominant firms: A note on the evidence from the Italian banking industry", Journal of Banking \& Finance, Vol. 29. No. 5, pp. 1083-1093. 
17. Coccorese, P. (2008a), "An investigation on the causal relationships between banking concentration and economic growth, International Review of Financial Analysis", Vol. 17. No. 3, pp. 557-570.

18. Coccorese, P. (2008b), "Bank competition and regional differences", Economics Letters, Vol. 101 No. 1, pp. 13-16.

19. Coccorese, P. (2009), "Market power in local banking monopolies", Journal of Banking \& Finance, Vol. 33. No. 7, pp. 1196-1210.

20. Coccorese, P. (2013), "Assessing the competitive conditions in the Italian banking system: some empirical evidence", PSL Quarterly Review, Vol. 51. No. 205, pp. 171-191.

21. Coccorese, P., Pellecchia, A. (2013), "Multimarket contact, competition and pricing in banking", Journal of International Money and Finance, Vol. 37, pp. 187214.

22. Dahl, D., Shrieves, R. E. (1999), "The extension of international credit by US banks: a disaggregated analysis 1988-1994", Journal of International Money and Finance, Vol. 18. No. 1, pp. 153-167.

23. Delis, M. D. (2010), "Competitive conditions in the Central and Eastern European banking systems", Omega, Vol. 38. No. 5, pp. 268-274.

24. Delis, M. D., Staikouras, K. C., Varlagas, P. T. (2008), "On the Measurement of Market Power in the Banking Industry", Journal of Business Finance \& Accounting, Vol. 35. No. 7, pp. 1023-1047.

25. Fosu, S. (2013), "Banking competition in Africa: Subregional comparative studies", Emerging Markets Review, Vol. 15, pp. 233-254.

26. Hondroyiannis, G., Lolos, S., Papapetrou, E. (1999), "Assessing competitive conditions in the Greek banking system", Journal of International Financial Markets, Institutions and Money, Vol. 9. No. 4, pp. 377-391.

27. Gischer, H., Stiele, M. (2009), "Competition Tests with a Non-Structural Model: the Panzar-Rosse Method Applied to Germany's Savings Banks", German Economic Review, Vol. 10. No. 1, pp. 50-70.

28. Goddard, J., Wilson, J. O. S. (2009), "Competition in banking: A disequilibrium approach", Journal of Banking \& Finance, Vol. 33. No. 12, pp. 2282-2292.

29. Günalp, B., Çelik, T. (2006), "Competition in the Turkish banking industry", Applied Economics, Vol. 38. No. 11, pp. 1335-1342.

30. Hondroyiannis, G., Lolos, S., Papapetrou, E. (1999b), "Assessing competitive conditions in the Greek banking system", Journal of International Financial Markets, Institutions and Money, Vol. 9. No. 4, pp. 377-391.

31. Kasman, A. (2010), "Consolidation and Competition in the Banking Industries of the EU Member and Candidate Countries", Emerging Markets Finance and Trade, Vol. 46. No. 6, pp. 121-139.

32. Klein, M. A. (1971), "A Theory of the Banking Firm", Journal of Money, Credit and Banking, Vol. 3. No. 2, pp. 205.

33. Lerner, A. P. (1934), "The Concept of Monopoly and the Measurement of Monopoly Power", The Review of Economic Studies, Vol. 1. No. 3, pp. 157-175.

34. Liu, H., Molyneux, P., Nguyen, L. H. (2012), "Competition and risk in South East Asian commercial banking", Applied Economics, Vol. 44. No. 28, pp. 3627-3644.

35. Liu, H., Molyneux, P., Wilson, J. O. S. (2013), "Competition and Stability in European Banking: A Regional Analysis", The Manchester School, Vol. 81. No. 2, pp. 176-201.

36. Lloyd-Williams, D. M., Molyneux, P., Thornton, J. (1994), "Market structure and performance in Spanish banking", Journal of Banking \& Finance, Vol. 18. No. 3, pp. 433-443.

37. Majid, M. Z. A., Sufian, F. (2006), "Consolidation and Competition in Emerging 
Market: An Empirical Test for Malaysian Banking Industry", Economic Change and Restructuring, Vol. 39 No. 1-2, pp. 105-124.

38. Mamatzakis, E., Staikouras, C., Koutsomanoli-Fillipaki, N. (2005), "Competition and concentration in the banking sector of the South Eastern European region", Emerging Markets Review, Vol. 6. No. 2, pp. 192-209.

39. Masood, O., Sergi, B. S. (2011a), "China's banking system, market structure, and competitive conditions", Frontiers of Economics in China, Vol. 6. No. 1, pp. 22-35.

40. Matthews, K., Murinde, V., Zhao, T. (2007), "Competitive conditions among the major British banks", Journal of Banking \& Finance, Vol. 31. No. 7, pp. 2025-2042.

41. Maudos, J., Solís, L. (2009), "The determinants of net interest income in the Mexican banking system: An integrated model", Journal of Banking \& Finance, Vol. 33. No. 10, pp. 1920-1931.

42. Memić, D., Škaljić-Memić, S. (2013), "Performance Analysis and Benchmarking of Commercial Banks Operating in Bosnia and Herzegovina: a DEA Approach", Business Systems Research, Vol. 4. No. 2, pp. 17-37.

43. Mishkin, F.S. (2013). The Economics of Money, Banking and Financial Institutions, Pearson.

44. Molyneux, P., Forbes, W. (1995), "Market structure and performance in European banking", Applied Economics, Vol. 27. No. 2, pp. 155-159.

45. Molyneux, P., Lloyd-Williams, D. M., Thornton, J. (1994), "Competitive conditions in european banking", Journal of Banking \& Finance, Vol. 18. No. 3, pp. 445-459.

46. Molyneux, P., Thornton, J., Michael Llyod-Williams, D. (1996), "Competition and market contestability in Japanese commercial banking", Journal of Economics and Business, Vol. 48. No. 1, pp. 33-45.

47. Nathan, A., Neave, E. H. (1989), "Competition and Contestability in Canada's Financial System: Empirical Results", Canadian Journal of Economics, Vol. 22. No. 3, pp. 576-94.

48. Panzar, J. C., Rosse, J. N. (1982). Structure, Conduct, and Comparative Statistics. Bell Telephone Laboratories, Incorporated.

49. Panzar, J. C., Rosse, J. N. (1987), "Testing For "Monopoly" Equilibrium", The Journal of Industrial Economics, Vol. 35. No. 4, pp. 443.

50. Pawłowska, M. (2011), "Competition in the Polish Banking Market Prior to Recent Crisis for the Period 1997-2007 - Empirical Results Obtained with the Use of Three Different Models", Bank i Kredyt, Vol. 42. No. 5, pp. 5-40.

51. Pruteanu-Podpiera, A., Weill, L., Schobert, F. (2008), "Banking Competition and Efficiency: A Micro-Data Analysis on the Czech Banking Industry", Comparative Economic Studies, Vol. 50. No. 2, pp. 253-273.

52. Rezitis, A. N. (2010), "Evaluating the state of competition of the Greek banking industry", Journal of International Financial Markets, Institutions and Money, Vol. 20. No. 1, pp. 68-90.

53. Rhoades, S. A. (1993), "Herfindahl-Hirschman Index", The Federal Reserve Bulletin, Vol. 79, pp. 188-189

54. Ritter, L.S., Silber, W.L., Udell, G.F. (2014). Principles of Money, Banking \& Financial Markets, Pearson.

55. de Rozas, L. G. (2007), "Testing for competition in the Spanish banking industry: The Panzar-Rosse approach revisited", Banco de España Research Paper No. WP-0726. Banco de España.

56. Sanyal, P., Shankar, R. (2011), "Ownership, competition, and bank productivity: An analysis of Indian banking in the post-reform period", International Review of Economics \& Finance, Vol. 20. No. 2, pp. 225-247.

57. Shaffer, S. (1989), "Competition in the U.S. banking industry", Economics Letters, 
Vol. 29. No. 4, pp. 321-323.

58. Shaffer, S. (1993), "A Test of Competition in Canadian Banking", Journal of Money, Credit and Banking, Vol. 25. No. 1, pp. 49.

59. Shaffer, S., DiSalvo, J. (1994), 2Conduct in a banking duopoly", Journal of Banking \& Finance, Vol. 18. No. 6, pp. 1063-1082.

60. Slovin, M. B., Sushka, M. E., Polonchek, J. A. (1999), "An analysis of contagion and competitive effects at commercial banks", Journal of Financial Economics, Vol. 54. No. 2, pp. 197-225.

61. Staikouras, C. K., Koutsomanoli-Fillipaki, A. (2006), "Competition and Concentration in the New European Banking Landscape", European Financial Management, Vol. 12. No. 3, pp. 443-482.

62. Tabak, B. M., Fazio, D. M., Cajueiro, D. O. (2012), "The relationship between banking market competition and risk-taking: Do size and capitalization matter?", Journal of Banking \& Finance, Vol. 36. No. 12, pp. 3366-3381.

63. Trivieri, F. (2007), "Does cross-ownership affect competition?: Evidence from the Italian banking industry", Journal of International Financial Markets, Institutions and Money Vol. 17 No. 1, pp. 79-101.

64. Yanelle, M.-O. (1997), "Banking Competition and Market Efficiency", The Review of Economic Studies, Vol. 64. No. 2, pp. 215-239.

65. Yildirim, H. S., Philippatos, G. C. (2007a), "Restructuring, consolidation and competition in Latin American banking markets", Journal of Banking \& Finance, Vol. 31. No. 3, pp. 629-639.

66. Yildirim, H. S., Philippatos, G. C. (2007b), "Efficiency of Banks: Recent Evidence from the Transition Economies of Europe, 1993-2000", The European Journal of Finance, Vol. 13. No. 2, pp. 123-143.

\section{About the author}

Dr. Deni Memić holds a position of an assistant professor at Sarajevo School of Science and Technology teaching courses of Accounting, Advanced Financial Reporting, Risk Management, Money and Banking. Dr. Deni Memić is a licensed Investment advisor and Court expert. He is the youngest PhD in history of School of Economics and Business Sarajevo. Previously held positions of CRO at Privredna banka Sarajevo, Director of Retail Risk Management and Rehabilitation at Hypo Alpe Adria Bank. Main fields of expertize: banking, portfolio management, Basel Accords, IFRS standards, risk modelling, financial analysis, default prediction and others. Author can be contacted at deni.memic@ssst.edu.ba 


\section{Appendices}

\section{Appendix 1}

Descriptive statistics

\begin{tabular}{|l|c|c|c|c|c|}
\hline Variable & Minimum & Maximum & Sum & Mean & Std. Dev. \\
\hline logIR & 13,079 & 19,404 & 1952,018 & 16,974 & 1,276 \\
\hline $\log R$ & 13,835 & 19,608 & 1988,920 & 17,295 & 1,194 \\
\hline $\log ($ TR/ASS) & $-3,190$ & $-1,969$ & $-295,967$ & $-2,574$ & 0,209 \\
\hline $\log (1+R O A)$ & $-0,192$ & 0,056 & 0,114 & 0,001 & 0,025 \\
\hline $\log P F$ & $-4,564$ & $-2,257$ & $-391,231$ & $-3,402$ & 0,503 \\
\hline $\log P L$ & 9,231 & 10,594 & 1177,802 & 10,242 & 0,214 \\
\hline $\log P K$ & $-3,685$ & 1,803 & $-58,791$ & $-0,511$ & 0,934 \\
\hline $\log$ ASS & 17,026 & 22,175 & 2284,886 & 19,869 & 1,182 \\
\hline $\log$ CAPASS & $-8,178$ & $-0,457$ & $-225,103$ & $-1,957$ & 0,976 \\
\hline $\log$ LOANASS & $-1,636$ & $-0,192$ & $-57,636$ & $-0,501$ & 0,240 \\
\hline $\operatorname{logBR}$ & $-6,692$ & $-2,030$ & $-410,307$ & $-3,568$ & 1,097 \\
\hline $\log$ LTD & 0,479 & 5,293 & 130,906 & 1,138 & 0,588 \\
\hline
\end{tabular}

Source: Author's calculations

Appendix 2

Estimation results for the Bosnian banks (2008-2012) log-log regression model dependent variable: logIR

\begin{tabular}{|c|c|c|c|c|c|c|c|c|c|}
\hline \multirow[b]{2}{*}{$\begin{array}{c}\text { Model } \\
\text { variables }\end{array}$} & \multicolumn{3}{|c|}{ Whole country } & \multicolumn{3}{|c|}{ Federation B\&H } & \multicolumn{3}{|c|}{ Republika Srpska } \\
\hline & Coeff. & t-value & Sig & Coeff. & t-value & Sig & Coeff. & t-value & Sig \\
\hline Intercept & 1,746 & 1,596 & 0,113 & 1,718 & 1,346 & 0,183 & $-0,754$ & $-0,287$ & 0,776 \\
\hline $\log P F$ & 0,271 & 5,980 & 0,000 & 0,220 & 4,337 & 0,000 & 0,619 & 4,309 & 0,000 \\
\hline $\log P L$ & $-0,213$ & $-2,001$ & 0,048 & $-0,175$ & $-1,312$ & 0,194 & 0,166 & 0,702 & 0,489 \\
\hline $\log P K$ & 0,027 & 1,220 & 0,225 & 0,060 & 2,064 & 0,043 & $-0,002$ & $-0,037$ & 0,971 \\
\hline $\log A S S$ & 0,955 & 29,562 & 0,000 & 0,927 & 27,047 & 0,000 & 0,994 & 10,692 & 0,000 \\
\hline logCAPASS & 0,003 & 0,140 & 0,889 & 0,002 & 0,092 & 0,927 & 0,115 & 0,868 & 0,393 \\
\hline IogLOANASS & 0,522 & 6,213 & 0,000 & 0,510 & 4,168 & 0,000 & 1,028 & 4,371 & 0,000 \\
\hline $\log B R$ & 0,059 & 1,756 & 0,082 & 0,068 & 1,769 & 0,081 & 0,036 & 0,458 & 0,650 \\
\hline $\log L T D$ & $-0,124$ & $-3,012$ & 0,003 & $-0,068$ & $-1,609$ & 0,112 & $-0,675$ & $-3,776$ & 0,001 \\
\hline Dummy5 & 0,043 & 1,019 & 0,310 & 0,055 & 1,341 & 0,184 & $-0,139$ & $-0,719$ & 0,478 \\
\hline DummyE & $-0,059$ & $-1,469$ & 0,145 & & & & & & \\
\hline H-statistic & \multicolumn{3}{|c|}{0,084} & \multicolumn{3}{|c|}{0,105} & \multicolumn{3}{|c|}{0,783} \\
\hline Competition & \multicolumn{3}{|c|}{ Monopoly } & \multicolumn{3}{|c|}{ Monopoly } & \multicolumn{3}{|c|}{ Monopolistic competition } \\
\hline $\begin{array}{c}H_{0}: H=0 \\
(p<0,050)\end{array}$ & \multicolumn{3}{|c|}{ Not rejected } & \multicolumn{3}{|c|}{ Not rejected } & \multicolumn{3}{|c|}{ Rejected } \\
\hline $\begin{array}{c}H_{0}: H=1 \\
(p<0,050)\end{array}$ & \multicolumn{3}{|c|}{ Rejected } & \multicolumn{3}{|c|}{ Rejected } & \multicolumn{3}{|c|}{ Rejected } \\
\hline Adjusted $\mathbf{R}^{2}$ & \multicolumn{3}{|c|}{0,982} & \multicolumn{3}{|c|}{0,984} & \multicolumn{3}{|c|}{0,98} \\
\hline $\begin{array}{c}\text { \# of } \\
\text { observations }\end{array}$ & \multicolumn{3}{|c|}{115} & \multicolumn{3}{|c|}{78} & \multicolumn{3}{|c|}{37} \\
\hline
\end{tabular}

Source: Author's calculations 
Appendix 3

Estimation results for the Bosnian banks (2008-2012) log-log regression model dependent variable: $\log$ TR

\begin{tabular}{|c|c|c|c|c|c|c|c|c|c|}
\hline & \multicolumn{3}{|c|}{ Whole country } & \multicolumn{3}{|c|}{ Federation B\&H } & \multicolumn{3}{|c|}{ Republika Srpska } \\
\hline Model variables & Coeff. & $\begin{array}{c}t- \\
\text { value }\end{array}$ & Sig & Coeff. & $\begin{array}{c}t- \\
\text { value }\end{array}$ & Sig & Coeff. & $\begin{array}{c}t- \\
\text { value }\end{array}$ & Sig \\
\hline Intercept & 4,863 & 5,067 & 0,000 & 3,858 & 3,677 & 0,000 & $-0,712$ & $-0,348$ & 0,731 \\
\hline $\log P F$ & 0,224 & 5,630 & 0,000 & 0,277 & 6,640 & 0,000 & 0,242 & 2,164 & 0,040 \\
\hline $\log P L$ & $-0,478$ & $-5,109$ & 0,000 & $-0,262$ & $-2,384$ & 0,020 & $-0,290$ & $-1,567$ & 0,129 \\
\hline $\log P K$ & $-0,013$ & $-0,694$ & 0,489 & 0,017 & 0,718 & 0,475 & $-0,010$ & $-0,285$ & 0,778 \\
\hline $\log A S S$ & 0,945 & 33,321 & 0,000 & 0,888 & 31,516 & 0,000 & 1,138 & 15,701 & 0,000 \\
\hline IogCAPASS & 0,029 & 1,695 & 0,093 & 0,017 & 1,062 & 0,292 & 0,167 & 1,614 & 0,118 \\
\hline logLOANASS & 0,328 & 4,449 & 0,000 & $-0,006$ & $-0,063$ & 0,950 & 0,676 & 3,688 & 0,001 \\
\hline $\log B R$ & 0,064 & 2,180 & 0,032 & 0,094 & 2,976 & 0,004 & $-0,088$ & $-1,441$ & 0,161 \\
\hline $\log L T D$ & $-0,176$ & $-4,875$ & 0,000 & $-0,156$ & $-4,470$ & 0,000 & $-0,466$ & $-3,338$ & 0,002 \\
\hline Dummy5 & 0,004 & 0,101 & 0,920 & 0,028 & 0,834 & 0,407 & $-0,037$ & $-0,247$ & 0,807 \\
\hline DummyE & $-0,123$ & $-3,487$ & 0,001 & & & & & & \\
\hline H-statistic & \multicolumn{3}{|c|}{$-0,268$} & \multicolumn{3}{|c|}{0,033} & \multicolumn{3}{|c|}{$-0,058$} \\
\hline Competition & \multicolumn{3}{|c|}{ Monopoly } & \multicolumn{3}{|c|}{ Monopoly } & \multicolumn{3}{|c|}{ Monopoly } \\
\hline F-value for $\mathrm{H}=0$ & \multicolumn{3}{|c|}{ Rejected } & \multicolumn{3}{|c|}{ Not rejected } & \multicolumn{3}{|c|}{ Not rejected } \\
\hline F-value for $\mathrm{H}=1$ & \multicolumn{3}{|c|}{ Rejected } & \multicolumn{3}{|c|}{ Rejected } & \multicolumn{3}{|c|}{ Rejected } \\
\hline Adjusted $\mathbf{R}^{2}$ & \multicolumn{3}{|c|}{0,984} & \multicolumn{3}{|c|}{0,988} & \multicolumn{3}{|c|}{0,987} \\
\hline \# of observations & \multicolumn{3}{|c|}{115} & \multicolumn{3}{|c|}{78} & \multicolumn{3}{|c|}{37} \\
\hline
\end{tabular}

Source: Author's calculations

Appendix 4

Estimation results for the Bosnian banks (2008-2012) log-log regression model dependent variable: $\log (T R / A S)$

\begin{tabular}{|c|c|c|c|c|c|c|c|c|c|}
\hline \multirow[b]{2}{*}{$\begin{array}{c}\text { Model } \\
\text { variables }\end{array}$} & \multicolumn{3}{|c|}{ Whole country } & \multicolumn{3}{|c|}{ Federation B\&H } & \multicolumn{3}{|c|}{ Republika Srpska } \\
\hline & Coeff. & t-value & Sig & Coeff. & t-value & Sig & Coeff. & t-value & Sig \\
\hline Intercept & 4,863 & 5,067 & 0,000 & 3,858 & 3,677 & 0,000 & $-0,712$ & $-0,348$ & 0,731 \\
\hline $\log P F$ & 0,224 & 5,630 & 0,000 & 0,277 & 6,640 & 0,000 & 0,242 & 2,164 & 0,040 \\
\hline $\log P L$ & $-0,478$ & $-5,109$ & 0,000 & $-0,262$ & $-2,384$ & 0,020 & $-0,290$ & $-1,567$ & 0,129 \\
\hline $\log P K$ & $-0,013$ & $-0,694$ & 0,489 & 0,017 & 0,718 & 0,475 & $-0,010$ & $-0,285$ & 0,778 \\
\hline $\log A S S$ & $-0,055$ & $-1,951$ & 0,054 & $-0,112$ & $-3,971$ & 0,000 & 0,138 & 1,909 & 0,067 \\
\hline logCAPASS & 0,029 & 1,695 & 0,093 & 0,017 & 1,062 & 0,292 & 0,167 & 1,614 & 0,118 \\
\hline logLOANASS & 0,328 & 4,449 & 0,000 & $-0,006$ & $-0,063$ & 0,950 & 0,676 & 3,688 & 0,001 \\
\hline $\log B R$ & 0,064 & 2,180 & 0,032 & 0,094 & 2,976 & 0,004 & $-0,088$ & $-1,441$ & 0,161 \\
\hline $\log L T D$ & $-0,176$ & $-4,875$ & 0,000 & $-0,156$ & $-4,470$ & 0,000 & $-0,466$ & $-3,338$ & 0,002 \\
\hline Dummy5 & 0,004 & 0,101 & 0,920 & 0,028 & 0,834 & 0,407 & $-0,037$ & $-0,247$ & 0,807 \\
\hline DummyE & $-0,123$ & $-3,487$ & 0,001 & & & & & & \\
\hline H-statistic & \multicolumn{3}{|c|}{$-0,268$} & \multicolumn{3}{|c|}{0,033} & \multicolumn{3}{|c|}{$-0,058$} \\
\hline Competition & \multicolumn{3}{|c|}{ Monopoly } & \multicolumn{3}{|c|}{ Monopoly } & \multicolumn{3}{|c|}{ Monopoly } \\
\hline $\begin{array}{c}\text { F-value for } \\
\mathrm{H}=0\end{array}$ & \multicolumn{3}{|c|}{ Rejected } & \multicolumn{3}{|c|}{ Not rejected } & \multicolumn{3}{|c|}{ Not rejected } \\
\hline $\begin{array}{c}\text { F-value for } \\
\qquad \begin{array}{c}H=1 \\
\text { - }\end{array}\end{array}$ & \multicolumn{3}{|c|}{ Rejected } & \multicolumn{3}{|c|}{ Rejected } & \multicolumn{3}{|c|}{ Rejected } \\
\hline Adjusted $\mathbf{R}^{2}$ & \multicolumn{3}{|c|}{0,472} & \multicolumn{3}{|c|}{0,570} & \multicolumn{3}{|c|}{0,617} \\
\hline $\begin{array}{c}\text { \# of } \\
\text { observations }\end{array}$ & \multicolumn{3}{|c|}{115} & \multicolumn{3}{|c|}{78} & \multicolumn{3}{|c|}{37} \\
\hline
\end{tabular}

Source: Author's calculations 
Appendix 5

Estimation results for the Bosnian banks (2008-2012) log-log regression model dependent variable: $\log (1+R O A)$

\begin{tabular}{|c|c|c|c|c|c|c|c|c|c|}
\hline $\log (1+R O A)$ & \multicolumn{3}{|c|}{ Whole country } & \multicolumn{3}{|c|}{ Federation B\&H } & \multicolumn{3}{|c|}{ Republika Srpska } \\
\hline $\begin{array}{c}\text { Model } \\
\text { variables }\end{array}$ & Coeff. & t-value & Sig & Coeff. & t-value & Sig & Coeff. & t-value & Sig \\
\hline Intercept & $-0,022$ & $-0,178$ & 0,859 & $-0,216$ & $-1,655$ & 0,102 & $-0,458$ & $-1,482$ & 0,150 \\
\hline $\log P F$ & $-0,031$ & $-6,007$ & 0,000 & $-0,019$ & $-3,678$ & 0,000 & $-0,047$ & $-2,812$ & 0,009 \\
\hline $\log P L$ & $-0,027$ & $-2,204$ & 0,030 & 0,004 & 0,285 & 0,777 & $-0,033$ & $-1,198$ & 0,241 \\
\hline $\log P K$ & $-0,002$ & $-0,712$ & 0,478 & 0,000 & 0,132 & 0,895 & 0,008 & 1,378 & 0,180 \\
\hline logASS & 0,009 & 2,499 & 0,014 & 0,004 & 1,182 & 0,241 & 0,031 & 2,807 & 0,009 \\
\hline logCAPASS & 0,000 & 0,198 & 0,844 & $-0,001$ & $-0,276$ & 0,783 & 0,005 & 0,290 & 0,774 \\
\hline IogLOANASS & 0,027 & 2,814 & 0,006 & $-0,021$ & $-1,715$ & 0,091 & 0,041 & 1,485 & 0,149 \\
\hline $\log B R$ & $-0,003$ & $-0,848$ & 0,398 & $-0,003$ & $-0,719$ & 0,474 & $-0,016$ & $-1,717$ & 0,097 \\
\hline $\log L T D$ & 0,012 & 2,524 & 0,013 & 0,009 & 2,057 & 0,043 & 0,005 & 0,218 & 0,829 \\
\hline Dummy5 & $-0,005$ & $-1,055$ & 0,294 & $-0,004$ & $-1,010$ & 0,316 & $-0,001$ & $-0,044$ & 0,965 \\
\hline DummyE & $-0,004$ & $-0,802$ & 0,424 & & & & & & \\
\hline H-statistic & \multicolumn{3}{|c|}{$-0,060$} & \multicolumn{3}{|c|}{$-0,015$} & \multicolumn{3}{|c|}{$-0,073$} \\
\hline Equilibrium & \multicolumn{3}{|c|}{ Disequilibrium } & \multicolumn{3}{|c|}{ Equilibrium } & \multicolumn{3}{|c|}{ Disequilibrium } \\
\hline $\begin{array}{c}\text { F-value for } \\
H=0\end{array}$ & \multicolumn{3}{|c|}{ Rejected } & \multicolumn{3}{|c|}{ Not rejected } & \multicolumn{3}{|c|}{ Rejected } \\
\hline Adjusted $\mathbf{R}^{2}$ & \multicolumn{3}{|c|}{0,342} & \multicolumn{3}{|c|}{0,222} & \multicolumn{3}{|c|}{0,629} \\
\hline $\begin{array}{c}\text { \# of } \\
\text { observations }\end{array}$ & \multicolumn{3}{|c|}{115} & \multicolumn{3}{|c|}{78} & \multicolumn{3}{|c|}{37} \\
\hline
\end{tabular}

Source: Author's calculations 